\title{
The Impact of Trust on the Quality of Participation in Development
} The Case of Ukraine

\author{
Tadashi Hirai
}

\begin{abstract}
Participation is essential in societal development. Nevertheless, it still tends to be implemented unsystematically, and to be interpreted loosely without attention to context. For effective implementation, trust needs to be taken more seriously. The nexus between participation and trust plays a key role in societal processes toward democracy. Highlighting it is particularly relevant to the political, economic, cultural, and environmental transition in Ukraine, where participation is encouraged while the level of trust is fragile, resulting in multiple adverse effects on everyday life. Accordingly, this article investigates the significance of effectively implementing participation and the impact of trust upon its quality, depicting Ukraine as a counterexample. While participation is vital, it needs to be managed with care, according to the level of trust in society.
\end{abstract}

Keywords: adaptive preference, capability approach, corruption, human development, institutions, participation, social quality, trust, Ukraine

Participation is vital in societal development. It gives people a sense of ownership in their lives. It also renders development projects and practices both effective and accountable. To the extent that it has such significance, it is subject not only to being used loosely but also to being misused by accident, or deliberately, or in both ways.

Participation does not automatically deliver positive effects. Within an existing societal power structure, it might maintain an unwarrantable status quo or even possibly reinforce it. While the most powerful people enhance their power by making the best of their current status, the vulnerable maintain their status at best by observing social customs for good or ill. Tax avoidance is, for example, instanced as a sign of adaptive preference in the societies where it prevails. People might understand the reasons for paying taxes but will nevertheless avoid paying them, in order to survive in a corrupt society. A naïve application of participation would thus not only be ineffective, it would also be harmful. Empowerment would certainly help the vulnerable to improve their living conditions, but often only as a temporary measure. Unless the existing power structure is overturned, the vulnerable will continue to exist even if 
group membership changes over time. Yet, it would be unrealistic to expect that all inequalities in the power structure can be eliminated.

One strategy for escaping this quandary may be to enhance trust in societal relationships. As evidenced by many previous studies, trust plays a crucial role in mitigating uncertainty felt by individuals and institutions. In a society where trust is high, people are more likely to make decisions that prove beneficial in the long term, both for themselves and for others. In contrast, in a society where trust is low people are more likely to prefer short-term profits for themselves alone. This means that participation would never function in societies lacking in trust, since its members would deceive one another. Trust is thus essential for development in general and for participation in particular. In other words, trust is indispensable to societal progress toward a form of democracy that is inseparable from participation. For its cultivation, an institutional process is required to incentivize people to choose, of their own accord, a fairer society.

Moreover, a theoretical investigation into participation and trust is of particular significance for the societal processes in Central and Eastern Europe (CEE) in general and in Ukraine in particular. As will be shown in the section below reporting the results of my empirical study, Ukraine is in crisis in multiple ways. The combination in Ukraine of a low level of trust and a high level of participation could be truly detrimental. Inasmuch as the low level of trust in Ukraine has previously been acknowledged (e.g., Heyets 2019; Novakova 2017), the central aim of this article is to analyze how it impacts on people's participation and everyday lives. The quality of participation is indeed an essential theme of social quality, insofar as it concerns "a form of participation in which people are able to shape their own circumstances and contribute to social development in such a way that it will further social justice, solidarity, equal value and human dignity" (Beck et al. 2012: 69). This article seeks to gain insight into several characteristics of Ukraine relating to trust and participation. Comparing the results for Ukraine with those of research studies on different countries can put the former in broader perspective. For this article, the comparison has been made with the United Kingdom and Japan.

The article is structured as follows. First, it begins by reviewing the participatory approach and illustrating the human development and capability approach as an example of a naïve application of participation (i.e., conceptually imprecise and methodologically unsystematic), in spite of its influence in the field of development. Second, it addresses trust by clarifying its types and by justifying the focus upon institutions for its cultivation. Third, it illustrates the implications of the level of trust for the quality of participation by comparing Ukraine with two developed democracies, and then it analyzes people's everyday lives by comparing Ukraine with other postcommunist CEE countries, so as to highlight detrimental effects even in the CEE region as a consequence of a naïve application of participation. This is followed by a proposal that institutional intervention is needed in order to cultivate trust in society, which would then incentivize individuals to play their parts fairly, leading them to make participation yield benefits in the long term, both for themselves and for others. 


\section{Participation in Development}

Inspired by Paulo Freire's original work during the 1950s on "liberating" landless peasants by involving them in the process of development (Freire 1970), the participatory approach has proliferated in the field of development. It gained momentum, in part because of the influential contributions by Robert Chambers since the 1970s (e.g., Chambers 1983, 1997, 2002, 2017) and in part because of the failure of the top-down approaches by the Bretton Woods institutions in the 1980s, notoriously so in the case of the Structural Adjustment Programs (Cornia et al. 1987).

In theory, participation is beneficial in many ways. Its instrumental aims are to reflect local knowledge and to target the marginalized (e.g., the poor, the disabled, and women) by involving them in the development process (Chambers 1997). Its intrinsic aims are empowerment and the enhancement of subjective well-being by encouraging people to socialize (Frey 2008; Helliwell and Putnam 2004). However, in reality, it has not always presented such a rosy picture.

Participation cannot be implemented in a vacuum. Whenever participation is concerned, it is imperative to consider the complexities of power and power relations both from within and without (Cooke and Kothari 2001). Even so, it is important to acknowledge that participation does not solve every problem.

\section{Using Participation with Care}

The term "participation" has different meanings for different people (Pretty 1994; Pretty et al. 1995). In a way, this ambiguity would facilitate cooperation between multiple stakeholders as well as disciplines, for it is described as a "sure-fire winning word" (Apthorpe 1997) or a "master metaphor" (Mosse 2003). But this comes with a price: it allows participation not only to be used loosely but also to be misused. To avoid misuse, it is imperative to clarify the intended meaning of "participation" during implementation, owing to its contextual nature.

Participation can be dichotomized according to its intended use. On the one hand, it is used instrumentally for efficiency in development, on the grounds that people are likely to agree to projects in which they are personally involved. On the other hand, it is used intrinsically, on the grounds that participants are likely to be empowered as they gain new knowledge and awareness (Pretty 1995). The instrumental use is associated with a project-based or institutional perspective. This defines participation as a tool to achieve a pre-established goal determined by external agents, who then reflect participants' views in the project's design and implementation. The intrinsic use is in turn associated with a social movement perspective, so as to define it as an empowering process in which participants are mobilized to eliminate unjust hierarchies in society (Tufte and Mefalopulos 2009). On the whole, the instrumental use has more to do with efficiency and external power, while the intrinsic use has more to do with selfrealization and internal power. 
Alternatively, participation can be classified according to the extent of its involvement. First, Jules Pretty (1995) categorized participation into seven types: (1) manipulative participation; (2) passive participation; (3) participation by consultation; (4) participation for material incentives; (5) functional participation; (6) interactive participation; and (7) self-mobilization. These types range from more passive (e.g., participants are told what is to happen) to more active (e.g., participants take initiatives independently of external agents). The first four types are interpreted as either "superficial and fragmented achievements" (Rahnema 1992: 141) or as "non-participation" (Hart 1992: 8), in the sense that they would either have no lasting positive effect on participants' lives or they would even allow for manipulation (Pretty 1995). Subsequently, Andrea Cornwall (2003) categorized participation into four types: (1) functional participation; (2) instrumental participation; (3) consultative participation; and (4) transformative participation. In these types, the participants range across objects, instruments, actors, and agents. More recently, Thomas Tufte and Paolo Mefalopulos (2009) categorized participation into four types: (1) passive participation; (2) participation by consultation; (3) participation by collaboration; and (4) empowerment participation. The typologies by Pretty (1995), Cornwall (2003), and Tufte and Mefalopulos (2009) are listed in Table 1 below.

\begin{tabular}{|c|c|c|c|c|c|}
\hline \multirow{2}{*}{$\begin{array}{l}\text { Mode of } \\
\text { participation }\end{array}$} & \multirow{2}{*}{$\begin{array}{l}\text { Participants } \\
\text { viewed as }\end{array}$} & \multicolumn{3}{|c|}{ Typology } & \multirow{2}{*}{$\begin{array}{l}\text { Intrinsic / } \\
\text { instrumental } \\
\text { importance }\end{array}$} \\
\hline & & Pretty (1995) & Cornwall (2003) & $\begin{array}{l}\text { Tufte \& Mefalopulos } \\
\text { (2009) }\end{array}$ & \\
\hline \multirow{4}{*}{ 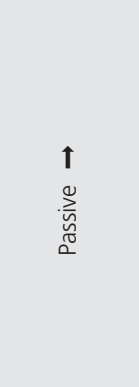 } & \multirow[t]{2}{*}{ Objects } & $\begin{array}{l}\text { Manipulative } \\
\text { participation }\end{array}$ & \multirow[t]{2}{*}{$\begin{array}{l}\text { Functional } \\
\text { participation }\end{array}$} & & \multirow{2}{*}{$\mathrm{n} / \mathrm{a}$} \\
\hline & & Passive participation & & Passive participation & \\
\hline & \multirow[t]{3}{*}{ Instruments } & $\begin{array}{l}\text { Participation by } \\
\text { consultation }\end{array}$ & \multirow[t]{3}{*}{$\begin{array}{l}\text { Instrumental } \\
\text { participation }\end{array}$} & $\begin{array}{l}\text { Participation by } \\
\text { consultation }\end{array}$ & \multirow{4}{*}{ 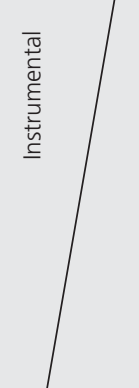 } \\
\hline & & $\begin{array}{l}\text { Participation for } \\
\text { material incentives }\end{array}$ & & & \\
\hline \multirow{3}{*}{ 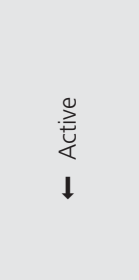 } & & $\begin{array}{l}\text { Functional } \\
\text { participation }\end{array}$ & & \multirow[t]{2}{*}{$\begin{array}{l}\text { Participation by } \\
\text { collaboration }\end{array}$} & \\
\hline & Actors & $\begin{array}{l}\text { Interactive } \\
\text { participation }\end{array}$ & $\begin{array}{l}\text { Consultative } \\
\text { participation }\end{array}$ & & \\
\hline & Agents & Self-mobilization & $\begin{array}{l}\text { Transformative } \\
\text { participation }\end{array}$ & $\begin{array}{l}\text { Empowerment } \\
\text { participation }\end{array}$ & $\begin{array}{l}\stackrel{.}{\underline{n}} \\
\stackrel{\underline{E}}{\underline{E}}\end{array}$ \\
\hline
\end{tabular}

Table 1. Typology of Participation (adapted from Pretty [1995], Cornwall [2003], and Tufte and Mefalopulos [2009]) 
As to the relevance of the above typologies to the dichotomy between the intrinsic and the instrumental importance of participation, no such importance applies to the case in which those who take part are regarded as objects. This is because participation there is not for those people themselves but for external agents (in the form of accountability to funding bodies). The importance of participation thus starts from the case in which those who take part are regarded as instruments. It appears that the main significance of participation in this phase is instrumental, albeit not purely so, since, to the extent that participants have a sense of ownership in the process, participation in this phase also has intrinsic importance. As the mode of participation moves into the active sphere, intrinsic importance becomes stronger until it surpasses instrumental importance by the time that participants are perceived as agents.

In addition to their typology reported above, which covers the overall process of the development project and practice, Tufte and Mefalopulos (2009) further classify the process in four stages: (1) research; (2) design; (3) implementation; and (4) evaluation. This classification relates to the types of participation regarding people as instruments. Otherwise, it is either irrelevant because the types are inapplicable to the more passive mode of participation, or it is less relevant because the types are intensely involved in more active modes of participation.

The above analysis underlines the importance of using the term "participation" carefully. It can be used without qualification only for the types where participants are regarded as actors or agents. It is only for these types that participation is relevant to all stages, that is, when participants are permitted a sense of ownership in their own lives during the development process. If the term "participation" is used loosely, when participants are viewed as objects or instruments, it is likely to be misused or to function ineffectively.

With that qualification, however, it is important to remember that participation is not a panacea. Indeed, when introducing his typology Pretty states that "self-initiated mobilization [i.e., self-mobilization] may or may not challenge existing distributions of wealth and power" (1995: 1252). ${ }^{1}$ More fundamentally, Chambers clearly states that participation "will not solve all the problems of the world; but it does open up some ways of trying to tackle these challenges" (1997: 103). In other words, conditions matter when we seek to optimize participation, since "reversals would be absurd if pushed to anarchy, dismantling the state, abolishing bureaucracy, removing all rules and controls" (1997: 211). Moreover, "dominant action can be needed, for instance to stop someone being beaten up, to insist on sound accounting or to combat corruption. Decisive leadership has its time and place" (1997: 213). These points imply that a top-down approach may be needed to overcome an unjustified status quo, even in the case of the most active mode of participation. The bottom line is that a top-down approach itself is not enough, and the same is true of a bottom-up approach. 


\section{Relevance to the Human Development and Capability Approach}

The human development approach was introduced in 1990 worldwide under the auspices of the United Nations Development Programme (UNDP) as an alternative to the orthodox economic growth model. Defined as "a process of enlarging people's choices" (UNDP 1990: 10), it emphasizes the enhancement of individual well-being in a multidimensional manner. This approach is philosophically supported by the capability approach introduced by Amartya Sen (1979), whose rationale was to establish an alternative to utilitarianism and the Rawlsian theory of justice. Thus, it advocates the necessity of reflecting people's values and reasoning for the evaluation of individual well-being. Given that choice, value and reasoning are taken seriously, participation is essential to the human development and capability approach. As things are, however, participation appears to be implemented through this approach in a problematic manner.

A rhetorical use of the term "participation" is found in the human development approach. As shown by Juan Telleria (2020), the UNDP promotes "development by the experts, for the people" rather than "development by the people, for the people" in its current version of participation. More broadly, Tadashi Hirai and colleagues (forthcoming) highlight a rhetorical use of the capability approach by the UNDP, which leads to the lack of context-specificity when implementing participation. Nevertheless, the capability approach itself seems to encounter difficulty when it comes to implementing participation.

Taking participation seriously, many of the scholars who work on the capability approach have attempted to put it into practice. Most recently, in pointing out the limited assessment of the methodological implications of applying participatory methods through the capability approach, scholars have advocated "the need to include and protect weak and vulnerable groups, ensure basic mechanisms of accountability, and subject deliberative processes to critical scrutiny" (Clark et al. 2019: 389). However, it seems unclear how participation could be applied systematically to meet those needs. First, it is good to include and protect the weak and the vulnerable, to the extent that they are empowered to tackle social injustice in the form of poverty and discrimination. But this would provide only a tentative solution so long as the root of the evil remains. Given that differences in power exist in any society, a more fundamental approach would be required in such a way as to "empower" the powerful as well to care for the weak and the vulnerable (i.e., empowerment in pursuit of not only biographical but also societal development [Herrmann 2012]).

Second, critical scrutiny is vital in deliberative processes, but the very core of the problem is the impossibility of such scrutiny in many contexts. A key example is corruption. If corruption prevails widely in society, people are more likely, even under scrutiny, to make use of corrupt practices to resist being disadvantaged. This applies especially to the weak and the vulnerable. Even though, in theory, one could propose to make their perspectives as wide as possible so that they escape from socially entrenched 
views (Sen 2009), it remains to be seen whether that escape can happen in practice. The Rawlsian "veil of ignorance" and the Smithian "impartial spectator" would be useful together as an institutional framework, but neither applies to a situation in which participants cannot afford to view their reality in the abstract. In addition, although the capability approach is seen to be beneficial to the participatory literature "by providing this comprehensive and flexible theory of well-being that can capture the multiple, complex and dynamic aspects of poverty" (Frediani et al. 2019: 10), the way in which capability theorists use the term "participation" seems less precise than the way it is in the existing participatory literature reviewed above.

It is thus unclear what precisely is meant by "participation" (i.e., importance, type, stage). The capability approach has been criticized for its lack of those institutions required for public reasoning and democracy, despite their central importance (Robeyns 2005). It is described as "one of the approach's relatively empty boxes" (Gasper 2007: 344). This criticism can be extended to participation. The term has been used as a black box in the capability approach. In this regard, Des Gasper further proposes the necessity of principles based in social theory, such as from the social quality approach, "to help identify priorities for the data collection and to better structure their presentation ... while it has a risk of itself being in some ways oversimplified" (2011: 102). Indeed, to overcome the overaccentuation of self-realization, the social quality approach highlights the constitutive interdependency between processes of self-realization and processes concerning the formation of collective identities within five frames of reference: the conceptual, the analytical, the procedural, the policy, and the normative framework (Beck et al. 2012).

To avoid its misuse and to make it function effectively, participation could be implemented more systematically according to context. Although, from its intrinsic perspective participation might be defended in any context, it risks aggravating an unjustified status quo both by strengthening the existing power structure at a collective level and by deepening the existing adaptive preferences at an individual level in addition to being inefficient from an instrumental perspective. A possible way of escaping the dilemma would be to implement participation according to the level of trust in society while concurrently taking action to cultivate that trust, so that participation could become more central to the process of development despite its limitations.

\section{Trust in Society}

Trust is indispensable for being human, given that humans are, as the Ancient Greek philosopher Aristotle (350 BCE) once remarked, "political animals." It lubricates the inevitable frictions of society (Putnam 2000) and thus plays a fundamental role in participation, democracy, and social stability (Eurofound 2012). Moreover, trust fosters socioeconomic progress, which in turn cultivates trust further (OECD 2017a). Unlike the use of "trust" in the social capital literature, where it strongly implies economic 
growth, trust in this article is interpreted as a constitutive element of social quality (Beck et al. 2012).

\section{Type of Trust and Its Significance}

According to the OECD Guidelines on Measuring Trust, trust is defined as "a person's belief that another person or institution will act consistently with their expectations of positive behaviour" (OECD 2017a: 42). It is conventionally distinguished between trust in other people (i.e., interpersonal trust) and trust in institutions (i.e., institutional trust) (Figure 1).

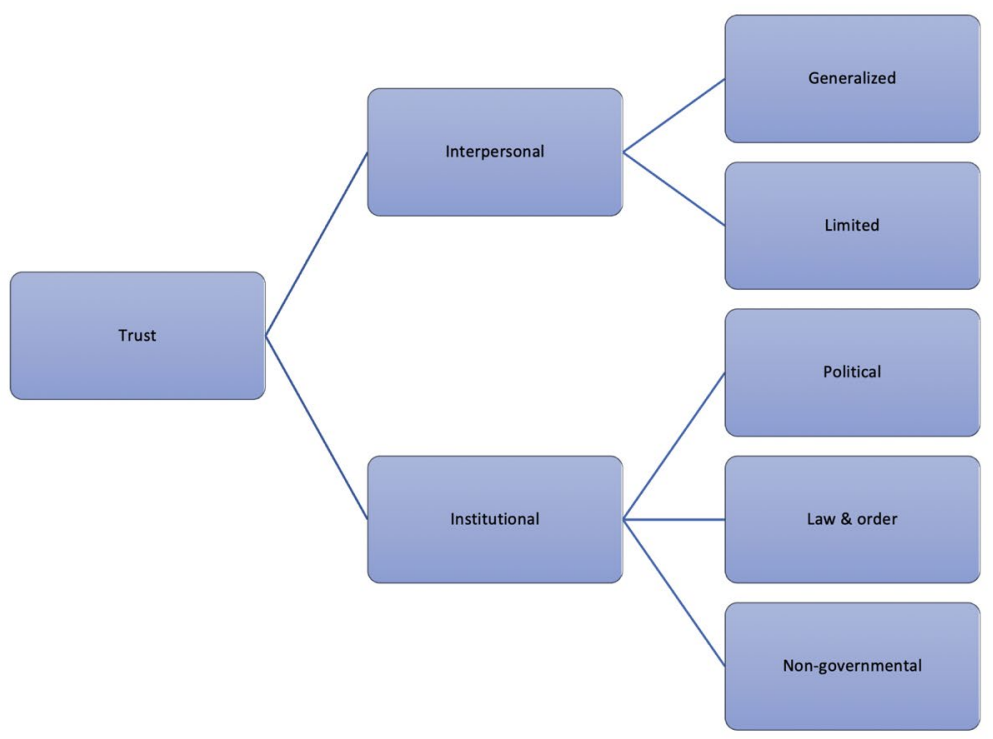

Figure 1. Trust Categorized by Coverage (adapted from OECD 2017a)

Interpersonal trust can be further categorized into two subtypes: generalized trust is the trust in people who are not known to the respondent, and limited trust is the trust in persons known to the respondent, such as family, friends, and neighbors (OECD 2017a). It has been established that the two types tend to be inversely related. People with strong family ties (i.e., strong limited trust) are more likely to have a lower level of trust in strangers (low generalized trust) than people with weak family ties, because of their limited level of outward exposure (Ermisch and Gambetta 2010). In society as a whole, generalized trust matters more, because it is associated more with the honesty and civic engagement required of good citizens (Putnam 2000).

In turn, institutional trust can be further categorized into three subtypes- trust in political institutions, trust in law and order institutions, and trust in nongovernmental institutions-but the distinction is not so common as that between generalized and limited trust, since there is little empirical evidence to suggest that people can make 
meaningful distinctions between these categories (OECD 2017a). Rather, institutional trust can be categorized more meaningfully by its drivers: trust in competence and trust in intentions (Figure 2).

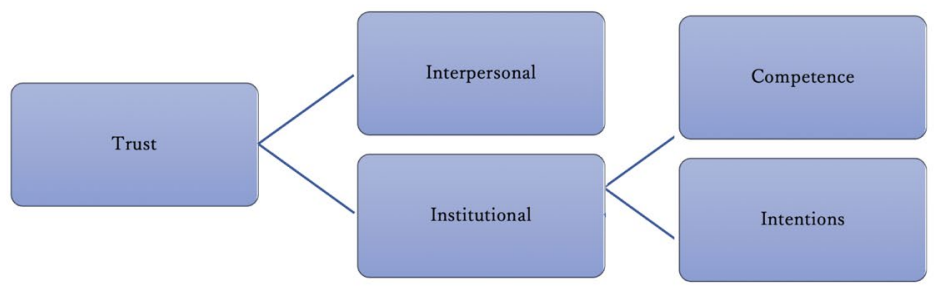

Figure 2. Trust Categorized by Driver (adapted from OECD 2017a)

Trust in competence refers to whether the functioning of institutions matches people's expectations of the competencies of those steering them, which is associated with responsiveness and reliability; and trust in intentions refers to whether institutions act in a way that people perceive as ethical, and which is associated with integrity, openness and fairness (Nooteboom 2007). Procedural fairness is fundamental to institutional trust (Tyler 1990), so that perceptions of corruption and discrimination impair trust more than functional competence or incompetence related to responsiveness and reliability (Eurofound 2018b; Murtin et al. 2018).

Overall, there is an interplay between interpersonal trust and institutional trust (Keele 2007). Institutional trust promotes interpersonal trust, to the extent that people are likely to extend risk-free trust to strangers when institutions are performing fairly and competently (Herrmann et al. 2008; Rothstein and Uslaner 2005; Tabellini 2008). Meanwhile, interpersonal trust promotes institutional trust, to the extent that institutions are likely to be fairer and more effective when individual civil servants have reason to believe that colleagues and citizens are trustworthy, and when the cost of corrupt behavior is high (Rothstein and Uslaner 2005).

Trust, both interpersonal and institutional, is strongly related to development. It is correlated positively with income/growth, education, and health (both in terms of mental and physical health). The correlation is negative with inequality, not only with income disparity but also with insecurity in the form of unemployment, adverse discrimination, and crime. Evidence for these relationships is assembled in the work of Yann Algan and Pierre Cahuc (2013), Eurofound (2012; 2018a; 2018b), Fabrice Murtin and colleagues (2018), the OECD (2011, 2017a), and others. Although the direction of causality is unclear (i.e., whether trust is a factor to enhance development or vice versa), the significance of trust for development in general is manifest. It is probable that flourishing societies enjoy both development and trust, whereas impoverished societies are caught in a vicious cycle without either trust or development. 


\section{Creating Trust}

It is not a straightforward task to change the level of trust in society, since trust may be deeply rooted in cultures. Nevertheless, levels of trust are not wholly resistant to change, as some studies of migrants show (Algan and Cahuc 2013; Guiso et al. 2004). Given the close association between interpersonal trust and institutional trust (Keele 2007) and the uncertainty as to whether interpersonal trust creates institutional trust or vice versa, it would be more practical to begin by cultivating institutional trust. There are many reasons for doing so. First, institutional trust is more volatile than interpersonal trust, partly because the former can be influenced by factors outside the general cultural background (Eurofound 2018b). This means that institutional trust will be enhanced by improving institutional performance, and particularly by clarifying institutional intentions. Second, institutional trust is more contagious in society than is the case with interpersonal trust. According to Bo Rothstein (2011), a substantial decline is observed both in generalized trust and in trust in civil servants when acceptance of a bribe by a police officer is witnessed. If so, the opposite would be also true-an increase (if not substantial) is expected in both interpersonal and institutional trust if fair procedures within institutions are acknowledged. Third, it is institutional trust that is required for long-term goals and thus for policy reforms. Interpersonal trust is important, as it relates closely to institutional trust, but interpersonal trust on its own would bring about social ills, in the shape of sectarianism and ethnocentrism, in the form of terrorism and organized crime (Putnam 2000). Moreover, in a society with low trust in institutions, people are more likely both to favor political candidates who promise immediate benefits and to disregard more fundamental issues (Eurofound 2018b). This is directly related to the quality of participation.

The cultivation of institutional trust would ideally be accomplished by government initiatives. However, there is an alternative method. Given the close parallel between trust-building by public institutions in OECD member states and the ways in which private companies routinely use trust to attract and retain customers (OECD 2017b), the practice can be extended to other parts of the world. In this context, external pressure to apply universal norms would be useful, for example if applied by a foreign company likely to make direct investments in line with SDG Goal 17 (Partnerships for the goals), as well as by the global monitoring of institutions in line with SDG Goal 16 (Peace, justice and strong institutions). ${ }^{2}$

\section{Trust and Its Relevance to Participation and Everyday Life}

While participation is intrinsically important for empowering people through the process of development, it is also instrumentally important for making development efficient. But if participation does not function well, it would result not only in rendering 
development inefficient but also in maintaining or aggravating inexcusable conditions. This is particularly the case when intrinsic importance is prioritized over instrumental importance when the conditions are not right. To make participation work in full, it is fundamentally important to cultivate trust in society; otherwise, people will arouse suspicion and secure their self-interest by cheating others, particularly when such practices prevail in society. It is applicable to everywhere but particularly to Ukraine, where participation is promoted in societal processes while the level of trust remains low, leading to unfavorable consequences in everyday life.

\section{Trust and Its Relevance to Participation: A Comparison between the United Kingdom, Japan and Ukraine}

To illustrate the impact of trust on the quality of participation, a comparative study was conducted between the United Kingdom, Japan, and Ukraine. The United Kingdom was selected as a representative of developed democracy in the West; Japan was selected as a representative of developed democracy in the Far East; and Ukraine was selected as a representative of emerging democracy in postcommunist Central and Eastern Europe. These three countries differ in many respects; however, their selection is intended to demonstrate the indispensability of institutional trust and participation anywhere around the world where democracy is a shared value. The data used here was obtained from the International Institute for Democracy and Electoral Assistance (IDEA) (2019), Transparency International (TI) (2019), and the World Economic Forum (WEF) (2018).

Beginning with the level of institutional trust, the following four categories were featured: "clean elections," "absence of corruption," "effective Parliament," and "reliability of police services." 3 The two former categories (i.e., "clean elections" and "absence of corruption") reflect institutional intentions (e.g., integrity, openness, fairness), and the two latter (i.e., "effective Parliament" and "reliability of police services") reflect institutional competencies (e.g., responsiveness, reliability). The conditions of each country are shown in the following figure (Figure 3). It was found that the United Kingdom and Japan have very similar trends in all four categories. Although the UK levels are higher on "clean elections," "absence of corruption," and "effective Parliament" while Japan has a higher level on "reliability of police services," the differences are marginal. By contrast, Ukraine reaches far lower levels than the United Kingdom or Japan in all four categories. Most seriously, the "absence of corruption" level is particularly low. This is a grave problem, since intention is more important than competency for institutional trust, as noted above.

Next, in order to investigate the environment and state of participation, the following four categories were investigated: "freedom of expression," "freedom of association and assembly," "personal integrity and security," and "civil society participation." The first three categories (i.e., "freedom of expression," "freedom of association and 
Institutional trust

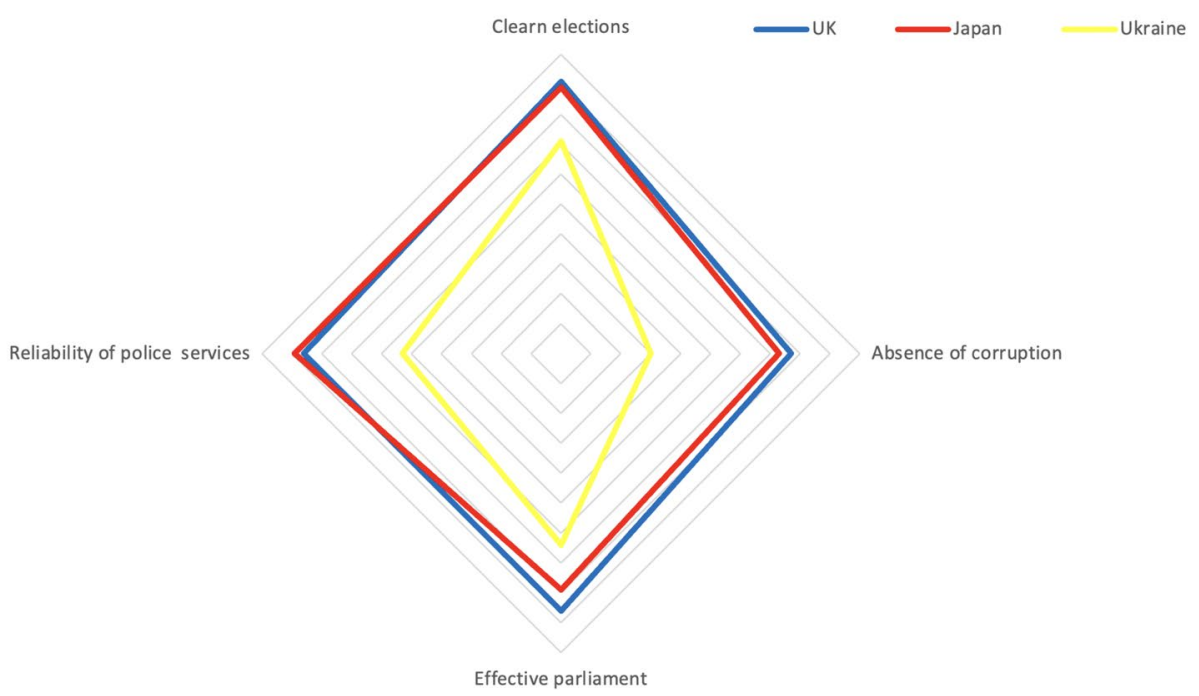

Figure 3. Institutional Trust: Intention and Competence (IDEA 2019; TI 2019; WEF 2018)

assembly," and "personal integrity and security") reflect the participatory environment, while the last one (i.e., "civil society participation") reflects the actual state of participation. The conditions of each country are shown in the following figure (Figure 4).

With respect to the participatory environment, these surveys suggest that the United Kingdom has the highest level of "freedom of expression" while Japan has the highest level of "freedom of association and assembly." This shows that people in the Western nations express their opinions individually, while people in the Eastern nations express their opinions more collectively (e.g., Schwartz and Bilsky 1990). By contrast, Ukraine again has the lowest level in both categories, which indicates greater constraint in expressing an opinion, regardless of whether it is done individually or collectively. These environments indeed affect "personal integrity and security." On the one hand, while people in Japan have the highest level of "personal integrity and security" by being collective and people in the United Kingdom have almost as high a level by being individual, this occurs regardless of collectivism or individualism; what matters is that each country has institutions that people can trust. On the other hand, because of the institutions that people in Ukraine cannot trust, they cannot enjoy the same level of safety. When it comes to the actual state of participation, however, a different picture emerges: although Ukraine retains the lowest level of "civil society participation" among the three countries, the difference between it and the other two is much narrower. In addition, the difference from Japan is only marginal. 


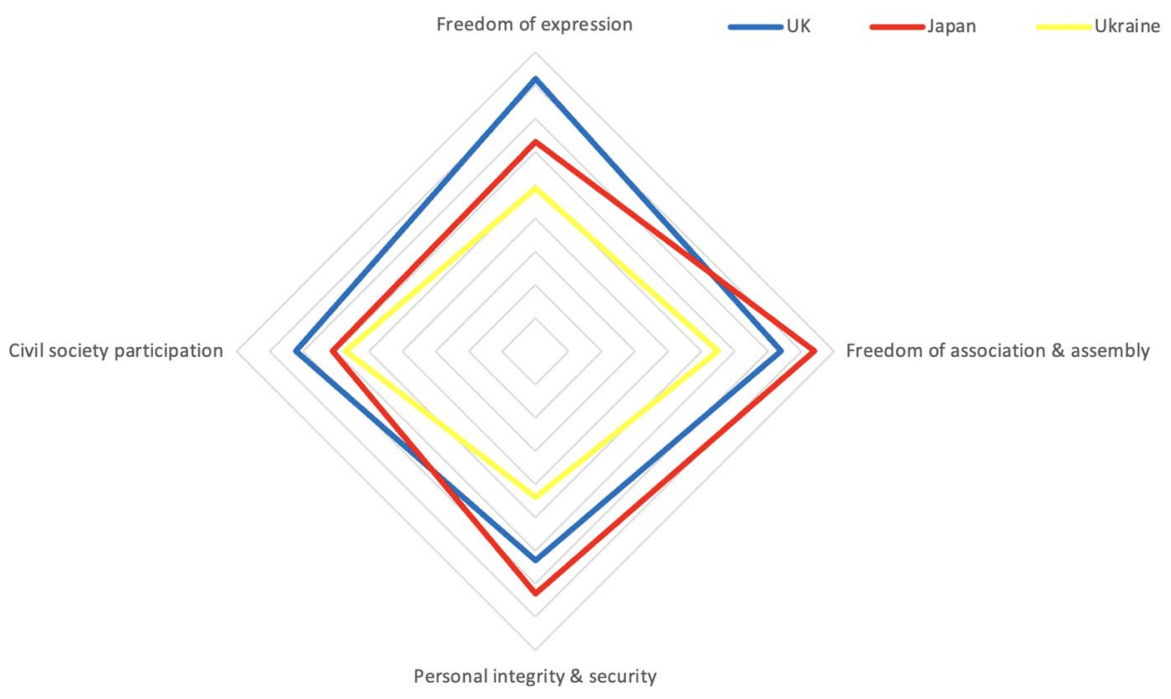

Figure 4. Participation: Environment and State (IDEA 2019)

\section{A Closer Look at Ukraine}

This finding, together with the above findings on institutional trust and the participatory environment, points to the probability of a naïve application of participation in Ukraine: participation is carried out even though its conditions are fragile, implying either that people will not express their personal opinion for fear of the existing power hierarchy, or that they will express an opinion in conformity with that hierarchy, depending on the topic under discussion.

This tendency is more applicable to Ukraine than to other postcommunist CEE nations. In the late 1990s, Ukraine had the lowest level of institutional trust in the region (Mishler and Rose 2001). ${ }^{5}$ This is reconfirmed by the latest data: "absence of corruption" is the second lowest (0.30 against 0.46$)$, "freedom of expression" and "freedom of association and assembly" are lower than the regional average (0.49 against $0.57 ; 0.55$ against 0.59 ), and "personal integrity and security" is the second lowest $(0.44$ against 0.60$)$, but "civil society participation" is higher than the regional average ( 0.57 against 0.52$)$. This leads to the conclusion that more caution will be required to implement participation in Ukraine than elsewhere in the CEE region, and much more so than in the United Kingdom or Japan, in order not to aggravate an unjustifiable status quo. 


\section{Everyday Life Subject to Trust and Participation in Ukraine}

The combination of a low level of trust and a high level of participation (i.e., a naïve application of participation) generates unfavorable consequences in everyday life. To understand multiple aspects of everyday life in the context of Ukraine, Zuzana Novakova (2017) proposes four dimensions: socioeconomic, sociopolitical, sociocultural, and socioenvironmental. What follows is an investigation of the implications of sociopolitical conditions (analyzed above in the form of trust and participation) for socioeconomic and sociocultural conditions that will compare the recent performance of Ukraine and other CEE countries. (The socioenvironmental dimension is not featured here, as it does not directly reflect everyday life despite its importance with respect to intergenerational justice.) The indicators used here follow and amplify those in the work of Valeriy Heyets (2019).

To examine socioeconomic conditions, four indicators have been selected: income (GDP per capita), labor productivity (GDP per person employed), the unemployment rate, and the consumer price index (Table 2). In the region, Ukraine has the worst performance in all four indicators both in terms of their current levels and in terms of their progress over time. On the one hand, income and labor productivity are less than half of the regional averages (US\$13.3k against US $\$ 30.5 \mathrm{k}$; US $\$ 29.2 \mathrm{k}$ against US\$62.4k). Progress in labor productivity is even lower, at only 90 percent of its level in 1991. On the other hand, the unemployment rate is more than 80 percent higher than the regional average ( 8.9 percent against 4.9 percent), while the consumer price index is twice as high as the regional average (281.7 against 125.5$)$. The hike in unemployment is particularly worth noting, given that many countries in the region have succeeded in its decline. Given that Ukraine performed moderately well in terms of income (US\$7.3k against US\$7.2k) and labor productivity (US\$30.9k against US $\$ 30.7 \mathrm{k}$ ) and far better in unemployment (1.9 percent against 5.9 percent) in the region around the time of independence, the current deteriorating conditions are outstanding. With that in mind, all this data needs to be considered with caution, given that the size of the shadow economy in Ukraine is around half of its official GDP ( 44.80 percent) and the highest in the region.

To examine the sociocultural conditions, seven indicators are selected: the Human Development Index (HDI) and its components (life expectancy, mean years of schooling, and expected years of schooling), government expenditure on health and on education, and income inequality (Table 3). ${ }^{6}$ Unlike the socioeconomic performances, the sociocultural conditions in Ukraine are mixed. On the one hand, Ukraine has the second lowest performances in the region on the HDI and longevity (one of the components of the HDI) (0.750 against $0.836 ; 72.0$ years against 76.2 years), and its rates of improvement from 1990 to 2018 are the lowest in the region (6.4 percent against 17.2 percent; 2.2 percent against 5.8 percent, respectively). Nevertheless, another component of the HDI (i.e., knowledge measured by mean and expected years of schooling) performs slightly lower than, but almost equivalent to, the regional average 
Table 2. Socioeconomic Dimension in Central Eastern Europe

\begin{tabular}{|c|c|c|c|c|c|c|c|c|c|c|c|c|c|c|c|}
\hline & \multicolumn{3}{|c|}{$\begin{array}{l}\text { Income (GDP per capita, PPP, current } \\
\text { international S, thousand) }\end{array}$} & \multicolumn{3}{|c|}{$\begin{array}{l}\text { Labor productivity (GDP per person employed, } \\
\text { constant } 2017 \text { PPPS, thousand) }\end{array}$} & \multicolumn{3}{|c|}{$\begin{array}{c}\text { Unemployment (\% of total labor force, lLO } \\
\text { estimate) }\end{array}$} & \multicolumn{3}{|c|}{ Consumer Price Index (2010=100) } & \multicolumn{3}{|c|}{$\begin{array}{c}\text { Size of shaddow economy (\% of GDP, } 1991 . \\
\text { 2015) }\end{array}$} \\
\hline Czech & 12.7 & 42.6 & 3.4 & 44.4 & 80.5 & 1.8 & 2.3 & 1.9 & -0.4 & 38.756 & 116.476 & 77.720 & 21.56 & 37.33 & 28.81 \\
\hline Hungary & 8.3 & 34.0 & 4.1 & 41.8 & 69.9 & 1.7 & 9.1 & 3.5 & -5.6 & 15.386 & 121.642 & 106.256 & 20.49 & 32.03 & 25.23 \\
\hline Poland & 6.2 & 34.2 & 5.5 & 25.7 & 71.2 & 2.8 & 12.1 & 3.0 & -9.1 & 18.036 & 114.112 & 96.076 & 16.67 & 30.21 & 25.10 \\
\hline Estonia & 5.8 & 38.8 & 6.7 & $26.1+$ & 72.9 & 2.8 & 1.5 & 5.4 & 3.9 & 11.638 & 122.142 & 110.504 & 27.52 & 30.51 & 23.80 \\
\hline Latvia & 5.5 & 32.2 & 5.9 & 24.6 . & 64.2 & 2.6 & 2.7 & 6.5 & 3.8 & 11.884 & 116.857 & 104.973 & 15.92 & 28.65 & 22.23 \\
\hline Lithania & 5.9 & 38.2 & 6.5 & 26.8 . & 75.5 & 2.8 & 1.1 & 6.3 & 5.2 & 4.179 & 118.382 & 114.203 & 17.62 & 32.49 & 25.15 \\
\hline Romania & 5.3 & 32.3 & 6.1 & 23.9 & 67.5 & 2.8 & 8.2 & 3.9 & -4.3 & 0.241 & 123.780 & 123.539 & 22.73 & 34.99 & 30.14 \\
\hline Bulgaria & 7.5 & 24.6 & 3.3 & 27.8 & 51.1 & 1.8 & 13.4 & 3.9 & -9.5 & 0.296 & 114.418 & 114.122 & 20.83 & 35.30 & 29.17 \\
\hline Ukraine & 7.3 & 13.3 & 1.8 & 30.9 & 29.2 & 0.9 & 1.9 & 8.9 & 7.0 & 0.004 & 281.659 & 281.655 & 36.65 & 57.00 & 44.80 \\
\hline AVERAGE & 7.2 & 30.5 & 4.4 & 30.7 & 62.4 & 2.1 & 5.9 & 4.9 & \begin{tabular}{|c|}
-1.0 \\
\end{tabular} & 11.129 & 136.616 & 125.487 & 23.40 & 36.92 & 29.94 \\
\hline
\end{tabular}

Table 3. Sociocultural Dimension in Central Eastern Europe

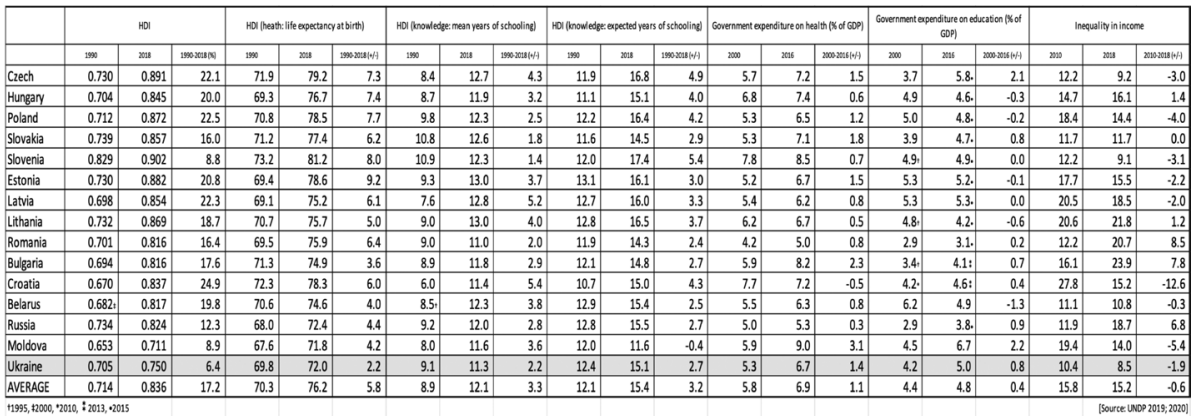

(11.3 against $12.1 ; 15.1$ against 15.4$)$. Government expenditure on health and on education is similarly almost equivalent to the regional averages (6.7 percent against 6.9 percent; 5.0 percent against 4.8 percent). Moreover, when it comes to income inequality, Ukraine performs best in the region over a decade (10.4 percent against 15.8 percent in $2010 ; 8.5$ percent against 15.2 percent in 2018 ). While the relatively good performance in the field of education is cheerful news, the discrepancy between government expenditure on health and the population's actual state of health is worth noting. This implies inefficiency in the field of health care (although life expectancy is not an ideal indicator for time sensitivity). Related to this, as is the case with the analysis of socioeconomic conditions, the level of income inequality also needs to be considered with caution in relation to the size of the shadow economy.

On top of all this data, people in Ukraine have had more direct experiences through their everyday lives: prolonged war with Russia and an unstable relationship with the European Union (Tamburelli 2016), a series of welfare reforms (e.g., in pensions, health care, education, utilities), and the lifting of a moratorium on agricultural land, all of which are about to be made subject to the market economy (Novakova 
2017). They each contribute to influence trust negatively in Ukraine, and trust in turn contributes to poor performances along socioeconomic and sociocultural dimensions. In such a context, participation is likely to be skewed in pursuit of short-term profits. This issue is all the more important in view of the ongoing decentralization reform, after which people will have more opportunity to participate in public life. It is time to take seriously an institutional intervention, possibly by an external enterprise, as will be argued in the next section.

\section{Calling for an Institutional "Nudge"}

To enhance institutional trust, its intentions, such as integrity, openness, and fairness, need to be addressed primarily, so that people's perceptions are altered. But this would not be achieved simply by promoting participation. For example, in a society where tax avoidance, a major indicator of corruption, is prevalent, people will probably choose not to pay taxes. So tax avoidance must be openly and successfully dealt with, and considerably reduced if not totally eliminated.

Indeed, tax avoidance would remain a rational choice in a society where any taxes that are collected were to be diverted to become the personal benefits of vested interests. People who decided to do otherwise would place themselves at a disadvantage, particularly if they were numbered among the deprived and the vulnerable. Participation in this context would tend to aggravate both the unjustified status quo at a collective level and adaptive preferences at an individual level. Public discussion as proposed by Sen would not be helpful, either. While it would be ideal to promote such discussion worldwide, it seems an unlikely prospect, particularly in the context of development practices in line with the bottom-up approach involving participation.

To get out of this problem, instead of relying on participation intervention would be required at an institutional level, and this could be represented as a "nudge" (Thaler and Sunstein 2009). To change people's behavior predictably and favorably, without prohibiting any options or changing any economic incentives, is "choice architecture" (Thaler and Sunstein 2009). For example, a tax-abiding enterprise could give stakeholders preferential access to its welfare facilities such as medical and learning services (high in quality and stable over time), so that nonstakeholders who had previously avoided paying taxes would have an incentive to join the enterprise in order to gain those benefits while paying taxes. In reality, apart from participation and public discussion, visible benefits are needed to change behaviors in a society where tax avoidance is prevalent, so as to demonstrate that those who live fairly will benefit in the long run and thus help to enhance trust in society. 


\section{Conclusion}

Participation is undoubtedly important in development. Nevertheless, too much reliance on participation alone without other institutional action could not only render development ineffective but also aggravate social ills. Participation is best encouraged not as a panacea but as one important component of a wider set of actions and even then with modest expectations, depending on the conditions where it is applied. It might be thus justified at all times from its intrinsic perspective but not necessarily so from an instrumental perspective.

Observing "the customs of the country" (such as tax avoidance) is grounded in human nature. Although people are able to acknowledge the "right" course of action, they may have good reasons to do otherwise in the light of their circumstances. So long as those customs are prevalent, reasoned discussion will not help very much, particularly with respect to the bottom-up approach associated with participation. Rather, it is both more important and more realistic to construct an institutional process to facilitate institutional trust for a fairer society, in which participation will be fully functional. In so doing, a tactical "nudge" would be required to incentivize people, rather than force them, to reduce social injustice.

To demonstrate the quality of participation and its relevance to trust, this article has undertaken a theoretical review of participation and trust, and applied its findings to the Ukrainian context. A comparison with two developed democracies- the United Kingdom and Japan — has revealed the problematic combination of a low level of trust and a high level of participation in Ukraine during its transition to a democracy. Moreover, a comparison with other CEE countries has revealed, as a consequence, distinctly unsatisfactory conditions in Ukrainian everyday life. This exercise could contribute to a future application of the social quality approach to Ukraine (as outlined in Van der Maesen 2019), in that it highlights an indissoluble connection between the sociopolitical dimension and the socioeconomic and sociocultural dimensions. More fundamentally, to the extent that "a form of participation" is essential to social quality, this exercise could yield significant insights into the relevance of trust to the quality of participation.

Development requires both bottom-up and top-down approaches. Too much focus on either of them would inevitably fail to make development effective and sustainable. This justifies the implementation of participation according to the level of trust while taking action to cultivate that trust.

Tadashi Hirai is Affiliated Lecturer and Research Associate at the University of Cambridge. He also works for a collective farm in Ukraine, which is establishing a social business. Email: hirai.tadashi@gmail.com 


\section{Acknowledgments}

I would like to thank Mr. Kensuke Ozaki for his insightful vision, as well as for his critical comments on his work through continuing discussion - and, of course, for his friendship. I also thank Professor Raymond Apthorpe, Professor Robert Chambers, Dr. Flavio Comim, Professor Sir Richard Jolly, Dr. Albert Park, and two editors, Dr. Laurent Van der Maesen and Dr. Zuzana Novakova, for their helpful comments on the manuscript. The text, as it now stands, is my responsibility and mine alone.

\section{Notes}

1. Related to this, the higher the ladder is not necessarily better-it all depends on context and purpose (personal communication with Robert Chambers, 29 August 2020).

2. $\mathrm{SDG}=$ Sustainable Development Goals. See https://www.un.org/sustainabledevelopment/sustainable -development-goals/.

3. The indicators used for "clean election" and "effective Parliament" are available in IDEA (2019); "absence of corruption" in TI (2019); and "reliability of police services" in WEF (2018).

4. The indicators used for all four categories are available in IDEA (2019).

5. The CEE nations included here are Belarus, Bulgaria, Czech, Hungary, Poland, Romania, Russia, Slovakia, and Slovenia.

6. The HDI is disaggregated here so as to better analyze the conditions of health and education.

\section{References}

Algan, Y., and P. Cahuc. 2013. Trust, Growth and Well-Being: New Evidence and Policy Implications. IZA Discussion Paper Series 7464. Bonn: IZA.

Apthorpe, R. 1997. "Writing Development Policy and Policy Analysis Plain or Clear: On Language, Genre and Power." In Anthropology of Policy: Critical Perspectives on Governance and Power, ed. S. Shore and S. Wright, 34-45. London: Routledge.

Aristotle. (350 BCE) 1996. The Politics and the Constitution of Athens. Edited by S. Everson. Cambridge: Cambridge University Press.

Beck, W., L. van der Maesen, and A. Walker. 2012. “Theoretical Foundation.” In Social Quality: From Theory to Indicators, ed. L. van der Maesen and A. Walker, 44-69. London: Palgrave Macmillan.

Chambers, R. 1983. Rural Development: Putting the Last First. London: Routledge.

Chambers, R. 1997. Whose Reality Counts? Putting the First Last. London: ITDG Publishing.

Chambers, R. 2002. Participatory Workshops: A Sourcebook of 21 Sets of Ideas and Activities. London: Earthscan.

Chambers, R. 2017. Can We Know Better? Reflections for Development. Rugby, UK: Practical Action Publishing.

Clark, D. A., M. Biggeri, and A. A. Frediani. 2019. "Participation, Empowerment and Capabilities: Key Lessons and Future Challenges." In The Capability Approach, Empowerment and Participation: Concepts, Methods and Applications, ed. D. A. Clark, M. Biggeri, and A. A. Frediani, 385-402. London: Palgrave Macmillan. 
Cooke, B., and U. Kothari, eds. 2001. Participation: The New Tyranny? London: Zed.

Cornia, G. A., R. Jolly, and F. Stewart, eds. 1987. Adjustment with a Human Face. Oxford: Clarendon Press.

Cornwall, A. 2003. "Whose Voices? Whose Choices? Reflections on Gender and Participatory Development." World Development 31 (8): 1325-1342. doi:10.1016/S0305-750X(03)00086-X.

Ermisch, J., and D. Gambetta. 2010. "Do Strong Family Ties Inhibit Trust?” Journal of Economic Behavior and Organization 75 (3): 365-376. doi:10.1016/j.jebo.2010.05.007.

Eurofound. 2012. NEETs_Young People Not in Employment, Education or Training: Characteristics, Costs and Policy Responses in Europe. Luxembourg: European Union.

Eurofound. 2018a. Social Cohesion and Well-Being in Europe. Luxembourg: European Union.

Eurofound. 2018b. Societal Change and Trust in Institutions. Luxembourg: European Union.

Frediani, A. A., D. A. Clark, and M. Biggeri. 2019. "Human Development and the Capability Approach: The Role of Empowerment and Participation.” In The Capability Approach, Empowerment and Participation: Concepts, Methods and Applications, ed. D. A. Clark, M. Biggeri, and A. A. Frediani, 3-36. London: Palgrave Macmillan.

Freire, P. (1970) 2017. Pedagogy of the Oppressed. London: Penguin.

Frey, B. S. 2008. Happiness: A Revolution in Economics. Cambridge, MA: MIT Press.

Gasper, D. 2007. "What Is the Capability Approach? Its Core, Rationale, Partners and Dangers." Journal of Socio-Economics 36 (3): 335-359. doi:10.1016/j.socec.2006.12.001.

Gasper, D. 2011. "The Human and the Social: A Comparison of the Discourses of Human Development, Human Security and Social Quality.” International Journal of Social Quality 1 (1): 91-108. https://www.jstor.org/stable/23971684.

Guiso, L., P. Sapienza, and L. Zingales. 2004. "The Role of Social Capital in Financial Development.” American Economic Review 94 (3): 526-556. https://www.jstor.org/stable/3592941.

Hart, R. A. 1992. Children's Participation: From Tokenism to Citizenship. Florence: UNICEF.

Helliwell, J. F., and R. D. Putnam. 2004. "The Social Context of Well-Being." Philosophical Transactions of the Royal Society of London. Series B: Biological Sciences 359 (1449): 1435-1446. doi:10.1098/rstb.2004.1522.

Herrmann, B., C. Thöni, and S. Gächter. 2008. “Antisocial Punishment across Societies.” Science 319 (5868): 1362-1367. http://www.jstor.com/stable/20053530.

Herrmann, P. 2012. "Social Empowerment." In Social Quality: From Theory to Indicators, ed. L. van der Maesen and A. Walker, 198-223. London: Palgrave Macmillan.

Heyets, V. 2019. "Social Quality in a Transitive Society." International Journal of Social Quality 9 (1): 32-50. doi:10.3167/IJSQ.2019.090103.

Hirai, T., F. Comim, and R. Jolly. Forthcoming. "Rescuing Human Development from a Lip-Service Syndrome." Online. Development Policy Review. doi:10.1111/dpr.12478.

IDEA (Institute for Democracy and Electoral Assistance). 2019. "The Global State of Democracy Indices.” https://www.idea.int/gsod-indices/\#/indices/world-map (accessed 20 July 2020).

Keele, L. 2007. "Social Capital and the Dynamics of Trust in Government." American Journal of Political Science 51 (2): 241-254. https://www.jstor.org/stable/4620063.

Mishler, W., and R. Rose. 2001. "What Are the Origins of Political Trust? Testing Institutional and Cultural Theories in Post-Communist Societies." Comparative Political Studies 34 (1): 30-62. doi:10.1177/0010414001034001002. 
Mosse, D. 2003. “The Making and Marketing of Participatory Development." In A Moral Critique of Development: In Search of Global Responsibilities, ed. P. Q. van Ufford and A. K. Giri, 43-75. London: Routledge.

Murtin, F., L. Fleischer, V. Siegerink, A. Aassveii, Y. Alganiii, R. Boarinii . . . and C. Smith. 2018. Trust and Its Determinants: Evidence from the Trustlab Experiment. OECD Statistics Working Paper 2018/02. Paris: OECD.

Nooteboom, B. 2007. "Social Capital, Institutions and Trust." Review of Social Economy 65 (1): 29-53. doi:10.1080/00346760601132154.

Novakova, Z. 2017. "Four Dimensions of Societal Transformation: An Introduction to the Problematique of Ukraine.” International Journal of Social Quality 7 (2): 1-29. doi:10.3167/ IJSQ.2017.070202.

OECD (Organisation for Economic Co-operation and Development). 2011. How's Life? Measuring Well-Being. OECD, Paris.

OECD (Organisation for Economic Co-operation and Development). 2017a. OECD Guidelines on Measuring Trust. Paris: OECD.

OECD (Organisation for Economic Co-operation and Development). 2017b. Trust and Public Policy: How Better Governance Can Help Rebuild Public Trust. OECD Public Governance Reviews. Paris: OECD.

Pretty, J. N. 1994. "Alternative Systems of Inquiry for a Sustainable Agriculture." IDS Bulletin 25 (2): 37-48. doi:10.1111/j.1759-5436.1994.mp25002004.x.

Pretty, J. N. 1995. "Participatory Learning for Sustainable Agriculture.” World Development 23 (8): 1247-1263. doi:10.1016/0305-750X(95)00046-F.

Pretty, J. N., I. Guijt, I. Scoones, and J. Thompson. 1995. Participatory Learning and Action: A Trainer's Guide. London: International Institute for Environment and Development.

Putnam, R. D. 2000. Bowling Alone: The Collapse and Revival of American Community. London: Simon \& Schuster.

Rahnema, M. 1992. "Participation." In The Development Dictionary: A Guide to Knowledge as Power, ed. W. Sachs, 127-144. London: Zed.

Robeyns, I. 2005. "The Capability Approach: A Theoretical Survey." Journal of Human Development 6 (1): 93-114. doi:10.1080/146498805200034266.

Rothstein, B. 2011. The Quality of Government: Corruption, Social Trust, and Inequality in International Perspective. Chicago: University of Chicago Press.

Rothstein, B., and E. M. Uslaner. 2005. "All for All: Equality, Corruption, and Social Trust.” World Politics 58 (1): 41-72. http://www.jstor.com/stable/40060124.

Schwartz, S. H., and W. Bilsky. 1990. "Toward a Theory of the Universal Content and Structure of Values: Extensions and Cross-Cultural Replications.” Journal of Personality and Social Psychology 58 (5): 878-891. doi:10.1037/0022-3514.58.5.878.

Sen, A. 1979. "Equality of What?” The Tanner Lecture on Human Values. https://tannerlectures.utah .edu/_documents/a-to-z/s/sen80.pdf (accessed 20 July 2020).

Sen, A. 2009. The Idea of Justice. London: Penguin.

Tabellini, G. 2008. "Institutions and Culture." Journal of the European Economic Association 6 (2-3): 255-294. doi:10.1162/JEEA.2008.6.2-3.255.

Tamburelli, G. 2016. “The Crisis in Ukraine.” La Comunità Internazionale 3/2016: 359-376. 
Telleria, J. 2020. "Development and Participation: Whose Participation? A Critical Analysis of the UNDP's Participatory Research Methods.” European Journal of Development Research. Online. doi:10.1057/s41287-020-00287-8.

Thaler, R. H., and C. R. Sunstein. 2009. Nudge: Improving Decisions about Health, Wealth and Happiness. London: Penguin.

TI (Transparency International). 2019. “Corruption Perceptions Index.” https://www.transparency.org/ en/cpi/2019/results (accessed 20 July 2020).

Tufte, T., and P. Mefalopulos. 2009. Participatory Communication: A Practical Guide. World Bank Working Paper 170. Washington, DC: World Bank.

Tyler, T. 1990. Why People Obey the Law. New Haven, CT: Yale University Press.

UNDP (United Nations Development Programme). 1990. Human Development Report. New York: UNDP.

UNDP (United Nations Development Programme). 2019. Human Development Report. New York: UNDP.

UNDP (United Nations Development Programme). 2020. "Human Development Data (19902018)." http://hdr.undp.org/en/data (accessed 27 November 2020).

Van der Maesen, L. 2019. Preliminary Ideas about the Application and Elaboration of the 'Social Quality Approach' (SQA) in Eastern Europe: The Case of Ukraine. IASQ Working Paper 17. Amsterdam: International Association on Social Quality. https://socialquality.org/wp-content/ uploads/IASQ-Working-Paper-17-4.pdf.

WEF (World Economic Forum). 2018. Global Competitiveness Report. Geneva: World Economic Forum. 